\title{
Distribution of Minois dryas (Scopoli, 1763) (Lepidoptera: Nymphalidae) in Poland - review of the current state and new data
}

\author{
Jarosław BURY \\ Markowa 1498,37-120Markowa, Poland; e-mail: jarekbury2@wp.pl
}

\begin{abstract}
A review of distribution of Minois dryas (Scopoli, 1763) in Poland is given together with new data on the occurrence. The material is based on observations obtained between 2002 and 2011 in Bieszczady Zachodnie, Beskid Niski, Pogórze Dynowskie, Pogórze Przemyskie and Pradolina Podkarpacka in Kotlina Sandomierska. New records of Minois dryas (Scopoli, 1763) refer to Pogórze Dynowskie and Pogórze Przemyskie. Its occurrence in Kotlina Sandomierska is confirmed.
\end{abstract}

Key words: Lepidoptera, Nymphalidae, Satyrinae, Minois dryas, endangered species, conservation, distribution, Poland

\section{INTRODUCTION}

The genus Minois Hübner, [1819] is represented globally by four species, of which one, Minois nagasawae (Matsumara, 1906), is endemic to the Alpine zone of Taiwanese mountains, two more, i.e. Minois paupera (Alphéraky, 1888) and Minois aurata (Oberthür, 1909), are distributed in Eastern Palaearctis, and Minois dryas (Scopoli, 1763) has a Euro-Siberian distribution (Fig. 1.) (Lewis 1974, Tuzov et al. 1997, Kudrna 2002, Huang, Hsu 2011, Karsholt, Nieukerken 2011).

The European range of $M$. dryas currently comprises 24 countries, from northern Spain, to the central and southern regions of the European mainland, to the European territory of Turkey and southern parts of Russia. The species is extinct in Luxembourg (Nekrutenko 1985, Tuzov et al. 1997, van Swaay \& Warren 1999, Kudrna 2002, Morgun 2002, Dovgailo 2003, Nekrutenko, Tshikolovets 2005).

In Asia, M. dryas has been recorded in an area extending from northern Turkey, Armenia, Georgia, Azerbaijan, and southern Russia, to northern Iran, Turkmenistan, Kazakhstan, Kyrgyzstan, to northern China, Mongolia, Korea, Japan and the Russian Far East (Nekrutenko 1990, Hesselbarth et al. 1995, Korshunov, Gorbunov 1995, Tuzov et al. 1997, Tshikolovets 1998, 2003, 2005, Tshikolovets et al. 2002, 2009a, 2009b, Nazari 2003, Gantigmaa 2004, Ler 2005, Toropov \& Zhdanko 2006, Koçak \& Kemal 2009, Kemal \& Koçak 2011).

A number of subspecies have been distinguished across this extensive distribution range. The nominal subspecies is found in the western part of the range, including Poland; spp. septentrionalis (Wnukowsky, 1929) is found in western and southern Siberia; ssp. bipunctatus (Motschulsky, 1860) has been recorded from the Amur and Ussuri Region, Sakhalin Island, Korea and Japan; spp. kurilensis Matsumara, 1928 has been found in the Kuril Islands; and ssp. shaanxiensis Qian \& Wei, 1994 in northern China (Chou 1994, Tuzov et al. 1997, Tshikolovets et al. 2002)

M. dryas was historically widely distributed in Poland (Romaniszyn \& Schille 1929, Dąbrowski 1994, 2004, Buszko \& Nowacki 2002, Buszko 2004), with most sites located in the north-east of Poland, mainly in Pomorze Zachodnie and the Noteć River Valley. Scattered records also originated from central and southern Poland, where the species was relatively less 
common. During the second half of the 20th century, a distinct decrease in the number of colonies had been observed, ultimately laeding to the extinction of the species from most known localities in Poland by the end of the 1980's. In the 1990's, the species persisted at its last natural site in the Skolczanka Reserve [DA 14] near Cracow and at sites near the Kajasówka Reserve [DA 04], in Bolechowice [DA15], Kobylany [DA16] and Klucze near Olkusz [CA97], where it was successfully introduced from 1973 to 1999 (Dąbrowski \& Krzywicki 1982, Dąbrowski 1994, 2004, Buszko, Nowacki 2002, Buszko 2004). On account of the rapid decline and considerable danger of complete extinction, it was included in the the Polish Red List of Near-Extinct and Endangered Animals, listed as critically endangered (CR) in the Polish Red List of Animal Species (Buszko \& Nowacki 2002, Buszko 2004), and given legal protection (Dziennik Ustaw 2004).

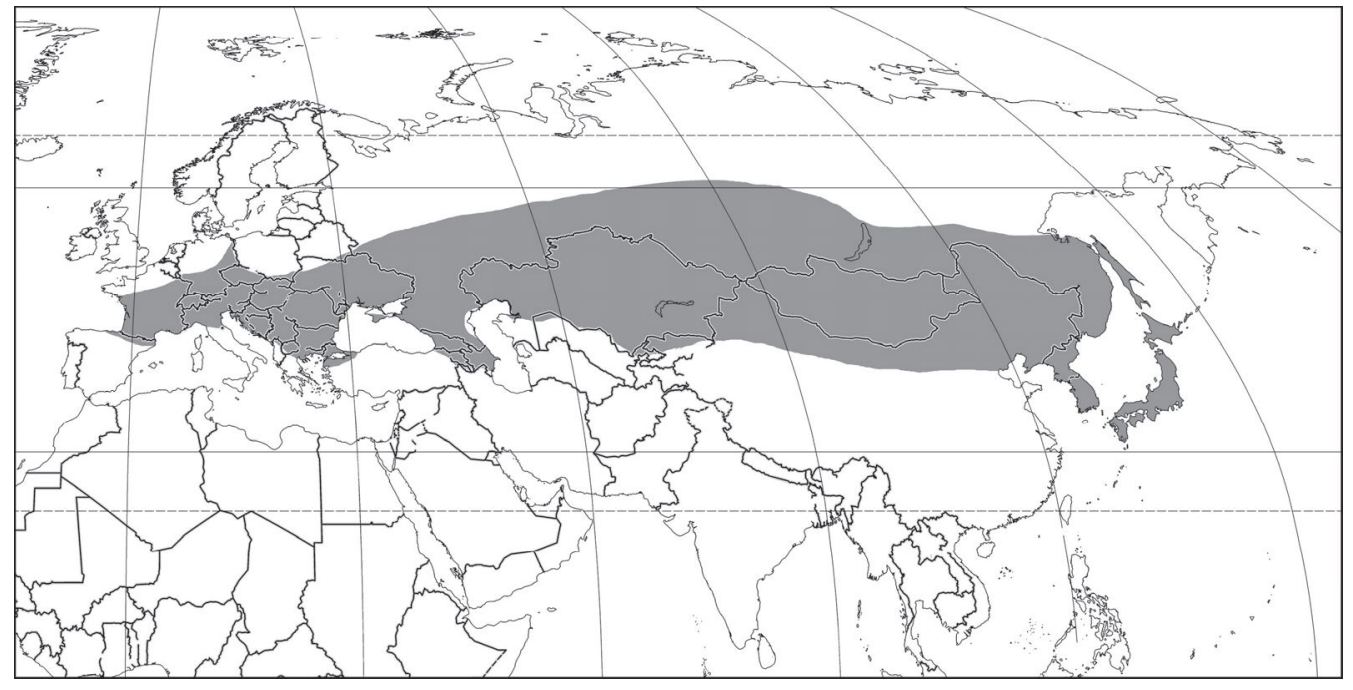

Fig. 1. Distribution range of Minois dryas (Scopoli, 1763).

The causes of such a fast rate of $M$. dryas decline in Poland are not wholly clear. Similar trends have been reported from neighbouring Germany and Czech Republic (Ebert \& Rennwald 1991, Settele et al. 1999, Beneš et al. 2002, Fiedler 2007), where the species has also been granted legal protection. Intensification of agricultural practices and natural succession of wooded plants have been listed as the most important causes of extinction, together with afforestation, which contributes to increasing isolation of individual sites and decreasing abundance of the butterflies in individual colonies (Settele et al. 1999, Beneš et al. 2002, Buszko 2004, Warecki \& Sielezniew 2008).

\section{LIFE HISTORY}

The life history of $M$. dryas has been relatively well known.

Habitat preferences: in Europe the species occupies two habitat types. In the larger part of the range, it is found in dry habitats, on thermophilous grasslands demonstrating various degrees of succession, shrubby meadows along forest edges and in habitats of the forest-steppe and steppe type, or even secondary habitats, such as disused overgrowing stone quarries and forest clearings. The other type is wet habitats, such as Molinia caerulea meadows in river valleys and fens. In the western part of its range, the species inhabits both habitat types, with 
a preference for wet ones in the north and dry ones in the south. However, this is not a rule, as shown by the presence of $M$. dryas on more humid sites, e.g. in the Czech Republic (Romaniszyn \& Schille 1929, Ebert \& Rennwald 1991, Kulfan at al. 1997, Settele 2000, Beneš $\&$ Vrabec 2002, Fiedler 2007, Bury 2010a) In the eastern part of the range, $M$. dryas is more flexible with regard to habitat choices and has even been regarded as a species without strict habitat preferences (Gantigmaa 2004).

Phenology: This is a univoltine species whose imagines are seen since late June and fly until early September, depending on the locality. For Central European populations, flight is usually confined to a period from mid-July to late August.

Behaviour of imagines: The butterfly is a heliophilous species showing marked protandry, which is characteristic of many species of the subfamily Satyrinae. Males establish territories that they survey from vantage points at the top of stony elevations or taller bushes. Two peaks of circadian flight activity are seen in the late morning and late afternoon. The butterflies eagerly visit flowers, in Central Europe mainly Lythrum salicaria L., Centaurea jacea L., Succisa pratensis Moench, Eupatorium cannabinum L., Betonica officinalis L., as well as Vincetoxicum hirundinaria Medik., Carlina acaulis L., Achillea millefolium L., Hypericum perforatum L., Clinopodium vulgare L., Coronilla varia (L.). The average life span in Europe is 25 days (Fiedler 2007, Buszko \& Maslowski 2008). Females have been seen to enter a summer diapause in warmer regions of Japan (Kida et al. 1997).

Females (Fig. 2.) shed eggs in flight or during short-timed sojourns among clusters of the caterpillars' host plants. The eggs are oval with a smooth surface and an egg volume of 0.64 . The egg stage takes approximately 30 days to complete (Garcia-Barros 2000, Fiedler 2007).

The caterpillars are oligophagous. In Central Europe they feed mainly on grasses of the species Bromus erectus Huds., Calamagrotis epigejos L., Festuca rubra L., Festuca ovina L., Arrhenatherum elatius (L.) J. Presl \& C. Presl, Brachypodium pinnatum (L.) P. Beauv., Molinia coerulea (L.) Moench, and Lolium perenne L. They can also be found on representatives of the genera Poa L. and Carex L., mainly Carex alba Scop., and Carex acutiformis L. (Spuler 1908, Ebert, Rennwald 1991, Beneš, Vrabec 2002, Nekruteno, Tshikolovets 2005, Fiedler 2007, Warecki, Sielezniew 2008). A few other host plants have been reported from the eastern part of the range, including Calamagrostis arundinacea (L.) Roth, Dactylis glomerata L., Bromus inermis Leyss. and Oryza sativa L. (Chou 1994, Korshunov \& Gorbunov 1995, Tuzov et al. 1997)

Caterpillars pursue a surreptitious life style, feeding mainly at dusk and during the night and spending the day deep inside tufts of their host plants, similarly to others related Satyrinae.

To survive winter caterpillars enter diapause during one of the early instars (L1 or L2). Breeders also report the wintering of fully developed L1 caterpillars in egg shells. After overwintering, caterpillars continue to develop and pupate after approximately 9-10 months in the immediate vicinity of their host plants, on the ground or buried shallowly underground. The pupal stage takes approximately 24 days to complete (Beneš et al. 2002, Settele et al. 1999, Fiedler 2007).

Population structure: while most observations have confirmed a sedentary mode of life of colonies that form metapopulations, findings of isolated individuals away from breeding sites indicate the possibility of long-distance dispersal flights to colonise new sites (Fiedler 2007).

The present paper is a review of current knowledge on the distribution of Minois dryas (Scopoli, 1763) in Poland and documents changes to its distribution range in Poland that have taken place in recent years. 


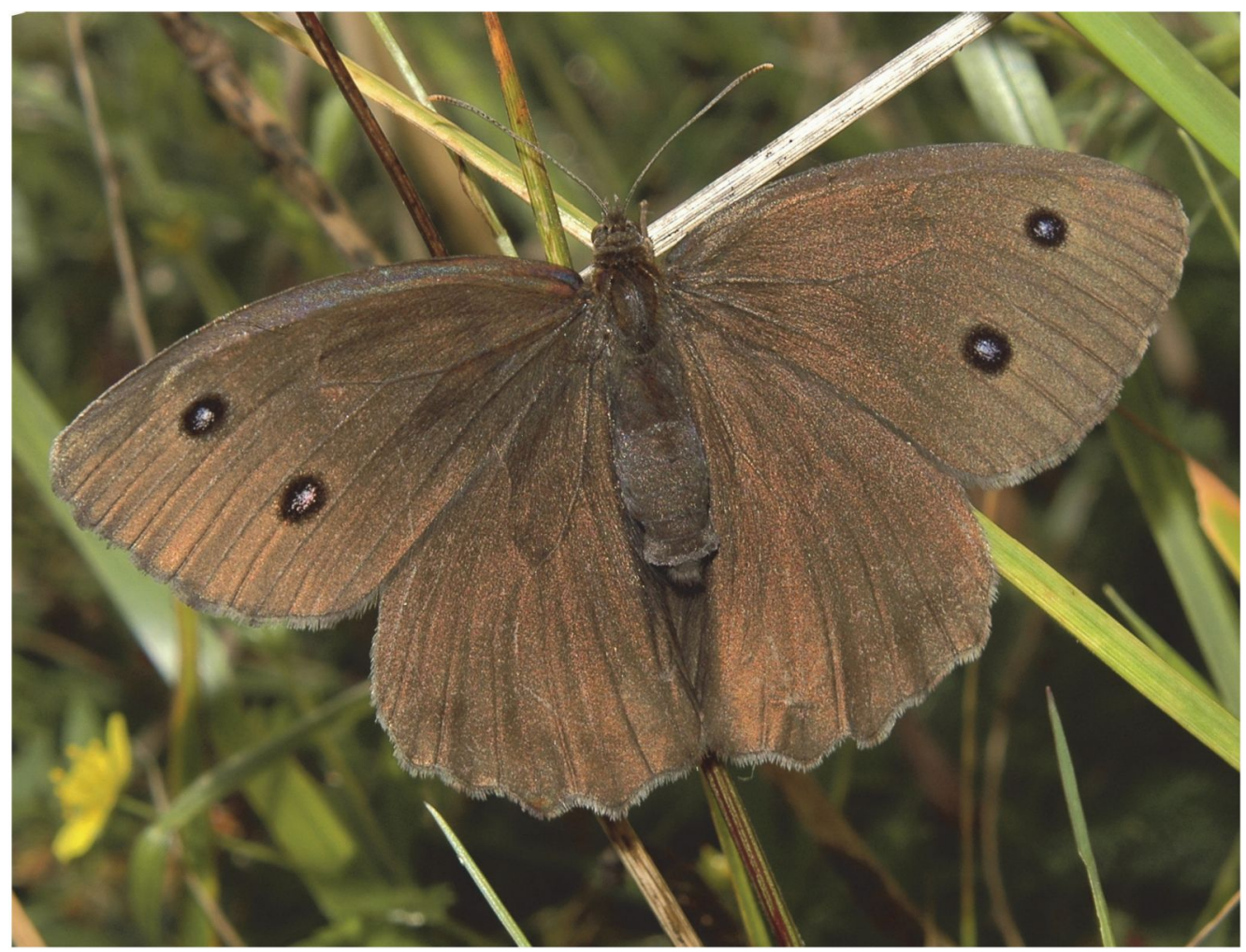

Fig. 2. Female of Minois dryas (Scopoli, 1763) - Poland, Beskid Niski Mts (fot. J. Bury).

\section{METHODS}

Fieldwork was carried out in south-eastern Poland, and more specifically in Bieszczady Zachodnie, Beskid Niski, Pogórze Dynowskie, Pogórze Przemyskie and Kotlina Sandomierska. The names of macro- and mesoregions are given according to "Geografia regionalna Polski" (Kondracki 2002). UTM (Universal Transverse of Mercator) co-ordinates (10x10 km grid) are also provided for each site

Butterflies were followed in their natural habitat. Their occurrence was documented by photographs.

\section{RESULTS}

Newly discovered sites:

1. Beskidy Lesiste - Bieszczady Zachodnie: Bóbrka [FV07] - an abandoned stone quarry, with SE-facing slopes exhibiting an early phase of succession of grassy vegetation. There are large patches of barren ground. The total area is $<0.5$ ha. The site is surrounded by a forest with a dominance of Larix decidua Mill. Population abundance: 20-30 individuals were observed on a sunny day, including a few females; a few individuals could be observed in cloudy weather. The site has been known since 31 VII 2010 and was monitored until 31 VII 2011. K. Mazur det. \& obs.

2. Beskidy Lesiste - Bieszczady Zachodnie: Baligród [EV96] - a SE mountain slope $500 \mathrm{~m}$ above sea level. The area has a dense cover of lush herbaceous vegetation as well as densely- 
growing grasses and sparse shrubs and trees. This is an extensive area covering a number of hectares. Population abundance: a dozen or so to more than 20 individuals, including a few females, could be seen during the day. The site has been known since 18-19 VIII 2006 and it was monitored until 08 IX 2009. P. Czudec, K. Mazur det. \& obs.

3. Beskidy Lesiste - Bieszczady Zachodnie: Cisna [EV95] - the SW slope of a hill. Grassy vegetation. The area has been used extensively as a pasture. It is a few hectares in area. Population abundance: a few individuals could be seen during the day. The site has been known since 15 VIII 2010. J. Bury det. \& obs.

4. Beskidy Środkowe - Beskid Niski: Klimkówka-Wietrzno [EV59] - a few localities.

4a. - a small clearing in a mixed forest overgrowing with Prunus spinosa L., S slope. Approximately 0.5 ha in area. Population abundance: approx. 10 individuals could be seen in one hour. The site has been known since 6 VIII 2008. W. Guzik det. \& obs.

4b. - a flat S slope, with sparse tree flora and shrubs: Prunus spinosa L., Quercus sp., Rosa $\mathrm{sp}$. The ground cover includes Sanguisorba officinalis L. and Geranium palustre L. Approx. 1 ha in area. Population abundance: one individual (male) was observed. The site has been known since 7 VIII 2009. W Guzik det.\& obs. Phengaris nausithous (Bergsträsser, 1779) and Phengaris teleius (Bergsträsser, 1779) have been recorded from there.

4c. - a forest clearing near a brook, almost completely covered with tufts of Rubus sp. and isolated Almus sp. trees. Approx. 0.1 ha in area. Population abundance: three males were observed on one occasion in 2008, and one female was observed in 2009. The site has been known since 6 VIII 2008; monitored on 10 VIII 2009. W. Guzik det. \& obs.

5. Beskidy Środkowe - Beskid Niski: Daliowa [EV57] - a dry clearing near a road in a mixed forest. Approx. 1 ha in area. Population abundance: only one female was observed. The site has been known since 29 VII 2011. W. Guzik det. \& obs.

6. Beskidy Środkowe - Beskid Niski: Krempna [EV38] - a neglected meadow overgrowing with Prumus spinosa L. on a S slope. The area is several hectares. The ground cover includes Thymus serpyllum L. The site is in close vicinity, though technically outside, of Magura National Park. Population abundance: only two individuals: a male and a female, were observed. Sympatric species, namely Iphiclides podalirius (Linnaeus, 1758) and Phengaris arion (Linnaeus, 1758), are present. The site has been known since 23 VII 2011. J. Wenta det. \& obs.

7. Pogórze Środkowobeskidzkie - Pogórze Dynowskie: Mójka [EA72] - wet forest meadows in the valley of a brook, within Mójka reserve, which is part of Hyżne-Gwoźnica Protected Landscape Area. The area is more than 10 hectares. Population abundance: several individuals were observed in 2002. The site has been known since July 2002. G. Paczka det. \& obs.

8. Pogórze Środkowobeskidzkie - Pogórze Przemyskie: Ulucz [EA90] - the SW slope of a hill. A dry meadow overgrowing with trees, adjacent to a forest. The area is approx. 1 ha. Population abundance: approx. 20 individuals were seen within less than an hour. The site has been known since 17 VIII 2011. W. Guzik det. \& obs.

9. Kotlina Sandomierska - Pradolina Podkarpacka: Rzeszów [EA74] - fallow meadows on the outskirts of a town, overgrowing with sparse tree vegetation. The area is several hectares. Population abundance: from several to more than ten individuals. The site has been known since July 2004. The site was monitored, and the presence of the butterflies was confirmed, until August 2010. P. Czudec det. \& obs.

\section{DisTRIBUTION}

M. dryas is here recorded for the first time in nine $10 \times 10 \mathrm{~km}$ UTM grid squares in Bieszczady Zachodnie, Beskid Niski, Pogórze Przemyskie, Pogórze Dynowskie and Pradolina Podkarpacka in Kotlina Sandomierska - UTM: [EA72, EA74, EA90, EV38, EV57, EV59, 
EV95, EV96, FV07]. These are the first records of this species in Pogórze Dynowskie (2002, by G. Pązka) and Pogórze Przemyskie (2011, by W. Guzik). Its presence has also been confirmed in Kotlina Sandomierska (2004, by P. Czudec), where it used to be known from one historical site in Mokra near Jarosław [FA13].

Thus, according to literature data, $M$. dryas has been recorded from a total of more than 50 UTM squares in Poland, (Scheffner 1925, Romaniszyn \& Schille 1929, Schramm 1948, Bielewicz 1973, Dąbrowski \& Krzywicki 1982, Krzywicki 1982, Dąbrowski 1994, 2004, Śliwiński 1996, Buszko 1997, 2004, Buszko \& Nowacki 2002, Warecki \& Sielezniew 2008) and new records (Fig. 3.). Most of the sites (about 30) are historical records. The species had become extinct from these sites by the 1980's.

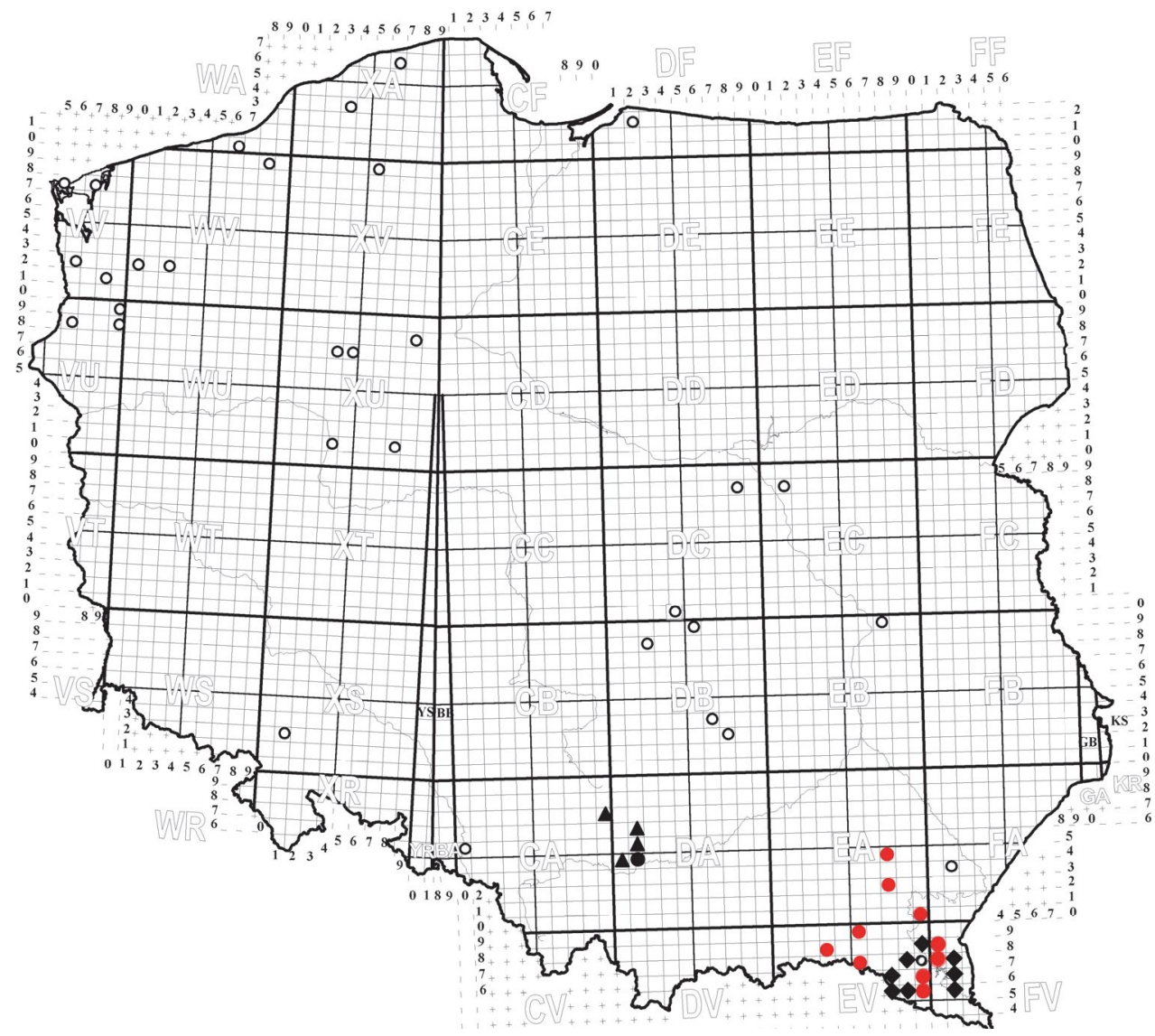

Fig. 3. Fig. 3. Distribution of Minois dryas (Scopoli, 1763) in Poland by Warecki \& Sielezniew 2008; white circles records before 1986 (Scheffner 1925, Romaniszyn \& Schille 1929, Schramm 1948, Bielewicz 1973, Dąbrowski \& Krzywicki 1982, Krzywicki 1982, Sliwiński 1996, Buszko 1997, 2004, Dąbrowski 2004); black circles - the "Skolczanka" nature reserve near Cracow, considered until 2008 as the only natural site (Buszko 1997, 2004, Dąbrowski 2004); black triangles - sites of successful introductions between 1973-1999 (Dąbrowski 1994, 2004); black diamonds - sites discovered in the Bieszczady Mts. and Beskid Niski Mts. (Warecki, Sielezniew 2008); red circles - newly discovered sites in Bieszczady Mts., Beskid Niski Mts., Przemyskie Foothills, Dynowskie Foothills and Sandomierska Plain. 
Discussion

M. dryas, once a widely distributed butterfly in northern and central Poland, has become almost completely extinct from most known sites over the last few decades (Dabrowski, Krzywicki 1982, Dąbrowski 1994, 2004, Buszko 1997, 2004, Buszko \& Nowacki 2002).

The discovery of multiple new sites of this species in south-eastern Poland (Warecki, Sielezniew 2008) radically changes this situation, indicating the possibility of wider $M$. dryas occurence in that part of the country where it has only been reported from the borderland between Pogórze Bukowskie and Bieszczady Zachodne (Olchowa kolo Leska [EV97] (Scheffner 1925, Romaniszyn \& Schille 1929, Schramm 1948, Bielewicz 1973)) and from Podgórze Rzeszowskie within Kotlina Sandomierska (Mokra koło Jarosławia [FA13] (Dąbrowski \& Krzywicki 1982).

The Olchowa site, however, was not included in subsequent studies, even as a historical site (Dąbrowski \& Krzywicki 1982, Krzywicki 1982, Buszko 1997, 2004, Buszko \& Nowacki 2002), and the authors of a recent paper on $M$. dryas erroneously report having made a first discovery of the species in the Bieszczady Mts. (Warecki \& Sielezniew 2008).

The lack of later records of this species in Bieszczady after 1948 might have been due to insufficient surveys of the entomofauna of the region, even though its Lepidoptera were quite well studied in the latter half of the 20th century. However, other explanations are also possible, including the extinction of local populations followed by re-settling of this area from hidden refuges in Poland, Slovakia, or Ukraine. The most probable hypothesis involves the resettling of the species in south-eastern Poland from areas to the south and east of Poland, where relatively abundant populations of $M$. dryas exist even though it is not legally protected either in Slovakia or in Ukraine (van Swaay \& Warren 1999, Kudrna 2002, Popov 2005), combined with influx from isolated preserved, but previously undiscovered, domestic sites, such as the Łupków locality [EV75] (Warecki \& Sielezniew 2008).

The discovery of a population of $M$. dryas in a wet locality within the Mójka reserve [EA72] south of the town of Rzeszów merits attention. In the light of this finding, the reports that this species occurs on wet meadows only in the north of Poland (Buszko 2004, Warecki, Sielezniew 2008) prove somewhat inaccurate. Still, it remains indisputable that Polish populations of the butterly are currently found mostly in dry habitats and that the species reaches the northern limit of its range in the south of Poland.

Of note is also the discovery of sites of $M$. dryas in Krempna [EV38] in the immediate vicinity of Magura National Park and in Rzeszów [EA74], in areas where recent studies of Rhopalocera did not reveal the presence of this species (Kosior \& Witkowski 2000, Olbrycht \& Pączka 2004, Pawlowski 2009).

The latest information in the present paper must be regarded as preliminary in view of the lack of more detailed data. Nevertheless, it clearly shows progressive colonisation of south-east Poland by $M$. dryas, while also not ruling out the possibility of more sites of this species awaiting discovery in the south of Poland.

This increase in the number of occupied $M$. dryas sites in south-east Poland may be attributable to climatic changes in the recent decades. These changes results in shifts of the ecological niches of individual species, which may contribute to the colonisation of new areas (Settele et al. 2008). At present, these changes are contributing to the colonisation success of a number of southern and xerothermophilous insect species that are being reported for the first time, re-discovered, or rapidly increasing their ranges in Poland, for example the moths Dysgonia algira (Linnaeus, 1767), Therapis flavicaria (Denis et Schiffermüller, 1775), or the hymenopteran genus Sceliphron Klug, 1801 (Bury et al. 2009, Bury 2010b, 2011).

Owing to the noticeable increase in the number of $M$. dryas colonies in the south of Poland in recent years, it is desirable to further monitor these changes. 


\section{ACKNOWLEDGEMENTS}

I wish to thank all those who have contributed to the development of this article, and in particular Prof. Jaroslaw Buszko and the collectors of $M$. dryas records: Pawel Czudec, Wojciech Guzik, Kamil Mazur, Grzegorz Pączka, and Jarosław Wenta.

\section{REFERENCES}

BENEŠ J. \& VRABEC V. 2002. Okáč ovsový Minois dryas (SCOPOLI, 1763). In: BENEŠ J., KONVICKA M., DVORÁK J., Fric Z., HAVELDA Z., PAVlícKo A., VRABEC V. \& WEIDENHOFFER Z. Motýli Ceské republiky: Rozšírení a ochrana. Butterflies of the Czech Republic: Distribution and Conservation. I., II, pp. 511-513. Společnost pro Ochranu Motýlů, Praha, 857 pp.

BIELEWICZ M. 1973. Macrolepidoptera of Western Bieszczady Mts. and Przemyskie Foothills. Rocznik Muzeum Gómośląskiego w Bytomiu. Przyroda, Bytom, 7: 1-170.

Bury J. 2010a. Leksykon - motyle. In: BuszKo J., BuRY J., Wiatrak Z., Najpiękniejsze motyle i trzmiele Podkarpacia. Rzeszów, Libra, 137-171.

BURY J. 2010b. New and supplementary date on the occurrens of Therapis flavicaria (DENIS \& SCHEFFERMÜLLER, 1775) (Lepidoptera: Geometridae) from Poland. Acta Entomologica Silesiana 18: 37-39.

BURY J. 2011. Dysgonia algira (LINNAEUs, 1767), a new species for the Polish fauna (Lepidoptera: Erebidae). Acta entomologica silesiana 19: 87-90.

Btry J., Stdol D., ZIĘBA P. \& ŻyŁA W. 2009. New date of occurence of the genus Sceliphron KLUG 1801 (Hymenoptera, Sphecidae) in Poland. Acta Entomologica Silesiana 17: 11-18.

Buszko J. \& MAslowski J. 1993. Atlas motyli Polski. Część I. Motyle dzienne (Rhopalocera). Image, Warszawa, $269 \mathrm{pp}$.

BuszKo J. \& MAsŁowski J. 2008. Motyle Dzienne Polski. Koliber, Nowy Sąez, 274 pp.

BUSzKo J. \& NOWACKI J. 2002. Lepidoptera. In: Glowacinski Z. (ed.), Red list of threatened animals in Poland. Instytut Ochrony Przyrody PAN, Kraków, 264 pp.

BuszKo J. 1997. A distribution atlas of butterflies in Poland 1986-1995. Turpress, Toruń, 170 pp.

BUSzKo J. 2004. Minots dryas. In: GŁOWACINSKI Z., NOWACKI J. (eds.), Polish red data book of animals. Invertebrates, pp. 264-265. Instytut Ochrony Przyrody PAN \& Akademia Rolnicza im. A. Cieszkowskiego. Kraków-Poznań, XXX pp.

CHOU I. (ed.). 1994. Monographia Rhopalocerum Sinensium. Vol 1-2. Henan Science and Technology Press, China, $854 \mathrm{pp}$.

DABROWSKI J. S. 1994. Successful attempts of reintroduction of local populations of Lepidoptera from the species Zygaena carniolica (Zygaenidae) and Minois dryas (Satyridae) into protected areas of the southern Poland. Chrońmy Przyrodę Ojczystą 50 (2): 31-42.

DĄBROWSKI J. S. 2004. Results of an introduction of dryas satyr - Minois dryas dryas SCOPOLI, 1763 (Lepidoptera: Satyridae), a species being in danger to become extinct in Poland, on Kraków-Częstochowa upland during 19732004. Parki Narodowe i Rezerwaty Przyrody 23 (2): 311-321.

DĄBROWSKI J. S. \& KRZYWICKI M. 1982. Disappearing and threatened Lepidoptera on fauna of Poland. Studia Naturae B, 31: 1-171.

Dovgallo K. E., Solodovnikov I. A. \& Rubin N. I. 2003. The butterflies (Diurna, Lepidoptera) of Republic of Belarus. CD key and database on the basis of software „Lysandra“, Minsk.

Dziennik Ustaw 2004, nr 220, poz. 2237 z dnia 2004-10-11. Rozporządzenie Ministra Środowiska z dnia 28 września 2004 r. w sprawie gatunków dziko występujących zwierząt objętych ochroną. 15570-15582.

EBERT G. \& RENNWALD E. (ed.) 1991. Die Schmetterlinge Baden Württembergs, Band 2, Tagfalter II. E. Ulmer, Stuttgart, $535 \mathrm{pp}$.

FIEDLER G. 2007. Minois dryas (SCOPOLI, 1767) Eschen-Scheckenfalter. In: KLAUSNITZER B. \& REINHARDT R. (eds) Beiträge zur Insektenfauna Sachsens. Vol. 6: REINHARDT R., SBIESCHNE H., SETTELE J., FISCHER U. \& FIEDLER G.: Entomologische Nachrichten und Berichte 11: 541-545.

GANTAGMAA C. 2004. Butterfly communities in the natural landscape of West Khentej, northern Mongolia: diversity and conservation value. $\mathrm{PhD}$ thesis. University of Göttingen; http://www.sub.unigoettingen.de/ebene_1/diss/dissmathe_bio_06.html [25.09.2011]

GARCIA-BARRos E. 2000. Egg size in butterflies (Lepidoptera: Papilionoidea and Hesperiidae): a summary of data. Journal of Research on the Lepidoptera 35: 90-136.

Hesselbarth G., van OORSCHOT H. \& WAgENER S. 1995. Die Tagfalter der Türkei unter Berücksichtigung der angrenzenden Länder, 3 vols. - Verlag S. Wagener, Bocholt, Text volumes 1+2: 1354 pp., 36 colour pls., volume 3: 847 pp., 128 colour pls., 13 b/w pls., 346 maps.

Huang CHIA-Lung \& Hsu Yu-Feng. 2011. The Early Stages and Biology of Minois nagasawae (MATsumara) (Lepidoptera: Nymphalidae, Satyrinae), an Alpine Butterfly Endemic to Taiwan. Proceedings of the Entomological Society of Washington 113 (3): 325-334. 
KARSHOLT O. \& VAN NIEUKERKEN E. J. 2011. Fauna Europaea: Lepidoptera, Nymphalidae. Fauna Europaea, version 2.4., www.faunaeur.org [28.09.2011]

KEMAL M. \& KOÇAK A. Ö. 2011. A synonymical and distributional checklist of the Papilionoidea and Hesperioidea of the East Mediterranean countries, including Turkey (Lepidoptera). Priamus (Suppl.) 25: 1-162, 42 Pls.

KIDA, Y., NuMATA \& H. FUJI, H. 1997. Summer diapause in female adults of Minois dryas (Lepidoptera: Satyridae). Environmental Entomology 26: 201-206.

KOÇAK A. O. \& KEMAL M. 2009. Revised Checklist of the Lepidoptera of Turkey. Cent. ent. Stud., Priamus (Suppl.) 17: $1-253$.

KONDRACKI J. 2002. Geografia regionalna Polski. Państwowe Wydawnictwo Naukowe, Warszawa, 444 pp.

Korshunov Y. \& Gorbunov P. 1995. Dnevnye babochki aziatskoi chasti Rossii. Spravochnik. [Butterflies of the Asian part of Russia. A handbook]. Ural University Press, Ekaterinburg, 202 pp. [In Russian]

Kosion A. \& Witkowski Z. J. 2000. Motyle dzienne (Rhopalocera) Magurskiego Parku Narodowego. Parki Narodowe i Rezerwaty Przyrody 19 (2): 67-83.

KRZYWICKI M. 1982. Monografia motyli dziennych Polski. Papilionoidea i Hesperioidea (Lepidoptera). Lublin, 364 pp., 168 map, 17 tabl., 4 tabele (msc.).

KUDRNA O. 2002. The distribution Atlas of European Butterflies. Oedippus 20, 343 pp.

KULFAN M., DEGMA P. \& KALIVODA H. 1997. Lepidoptera of different grassland types across the Morava floodplain. Journal of Research on the Lepidoptera, 34: 39-47.

LEWIS H. L. 1974. Butterflies of the World. Follett Publishing Company, Chicago, 312 pp.

LER P. A. 2005. Key to the insects of Russian Far East. Vol. V. Trichoptera and Lepidoptera. Pt. 5. Dal'nauka, Vladivostok, 575 pp. [In Russian]

MorGUN D. V. 2002. Dnevnye babochki evropeiskoi Rossii i sopredelnyh stron. Opredelitel-Spravochnik. [Butterflies of European Russia and adjacent territories. A guide and a handbook.] MGSYN, Moscow, 208 pp. [In Russian]

MAEKI K. \& MAKINO S. 1953. Chromosom numbers of some Japonese Rhopalocera. Lepid. News, 7: 36-38.

NAZARI V. 2003. Butterflies of Iran. Department of Environment, Dayereye Sabz publications, Tehran, Iran. $568 \mathrm{pp.}$ 74 col. pls. [In Farsi]

NEKRUTENKO Y. P. 1985. The Butterflies of the Krimea. Naukova Dumka. Kyiv. 152 pp., 24 col. pls., 123 figs.

NekrutENKo Y. P. 1990. The Butterflies of the Caucasus. Vol. 1. Papilionidae, Pieridae, Satyridae, Danaidae. Naukova Dumka. Kiev (Ukraine). 215 pp., 32 col. pls., 106 figs.

NERRUtenKo Y. P. \& TShIKolovets. V. V. 2005. The Butterflies of Ukraine. Wildlife of Ukraine Field Guide Series. Rayevsky Scientific Publishers, Kyiv, 231 pp.

OlBRyCht T. \& PACzKa G. 2004. Motyle dzienne (Rhopalocera) Rzeszowa. Zeszyty Naukowe PohudniowoWschodniego Oddziału PTIE i PTG, Oddzial w Rzeszowie, 5: 21-26.

PAWŁowsKi J. 2009. Cenne bezkręgowee naziemne Magurskiego Parku Narodowego i terenów ościennych. In: GÓRECKI A. \& ZEMANEK B, (eds), Magurski Park Narodowy - monografia przyrodnicza, pp. $132-146$. Uniwersytet Jagielloński, Magurski Park Narodowy, Kraków-Krempna.

Popov S. G. 2005. SW Ukrainian butterfly database: report 1973-2005, Lepidoptera: Papilionoidea \& Hesperioidea. S. G. Popov. Uzhgorod.

http://www.alexanor.uzhgorod.ua/dmap0076.htm [31.08.2011]

ROMANISZYN J. \& SCHILLE, F. 1929. Fauna motyli Polski (Fauna Lepidopterorum Poloniae). 1. Prace Monograficzne Komisji Fizjograficznej 6: 57.

SCHEFFNER J. 1925. Die Schmetterlinge aus der Umgebung von Olchowa. Societas Entomologica 40 (10): 38-39.

SCHRAMM W. 1948. Motyle okolic Olchowy Ziemi Sanockiej, Poznańskie Towarzystwo Przyjaciół Nauk, ser. B, Poznań, 10 (6): 270-313.

SEtTele J. \& FELdMAnN R. \& REINHARDt R. (eds.) 2000. Die Tagfalter Deutschlands. Ulmer, Stuttgart, 450 pp.

Settele J., KudrNa O., Harpke A., Kuehn I., VAN SwaAy C., VerontK R., Warren M., Wiemers M., Hanspach

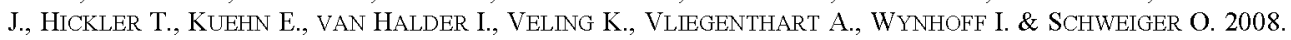
Climatic Risk Atlas of European Butterflies, Biorisk 1 (Special Issue), 710 pp.

SPULER A. 1908. Schmetterlinge Europas. 3 Auflage von Prof. E. Hoffmann's Werk: Die Groß-Schmetterlinge Europas. 1. Band Allgemeiner Teil: Rhopalocera, Hesperiidae, Sphingidae, Thaumotopoeidae, Drepanidae, Saturniidae, Lemoniidae, Endromididae, Lasiocampidae, Lymantriidae, Noctuidae, Cymatophoridae und Brephidae. Schweizerbartsche Verlagsbuchhandlung, Stuttgart, $385 \mathrm{pp}$.

ŚLIWINSKK Z. 1996. Motyle dzienne (Lepidoptera: Papilionoidea i Hesperioidea) Wyżyny Lódzkiej. Biuletyn Entomologiczny, Łódź, 2(14): 1-4.

TORopov S.A. \& ZHDANKO A.B. 2006. The butterflies (Lepidoptera, Papilionoidea) of Dzhungar, Tien Shan, Alai and Eastern Pamirs. Vol. 1. Papilionidae, Pieridae, Satyridae. Bishkek, 383 pp.

Tshikolovets V. V. 1998. The butterflies of Palaearctic Asia. Vol. 1. The Butterflies of Turkmenistan. Konvoj Ltd., Brno, 237 pp.

Tshikolovets V. V. 2003. Butterflies of Eastern Europe, Urals and Caucasus: An Illustrated Guide. Konvoj Ltd., Kyiv-Brno, 176 pp. 
Tshikolovets V. V. 2005. The butterflies of Palaearctic Asia. Vol. 6. The Butterflies of Kyrgyzstan. Konvoj Ltd., Brno-Kyiv, 512 pp.

Tshikolovets V. V., Bidzilya O. V. \& Golovischin M. I. 2002. The butterflies of Palaearctic Asia. Vol. 3. The Butterflies of Transbaikal Siberia. Konvoj Ltd., Brno-Kyiv, $320 \mathrm{pp}$.

Tshikolovets V.V., Yakovlev R., Balint Z. 2009a. The butterflies of Palaearctic Asia. Vol. 8. The Butterflies of Mongolia. Selbstverlag, Kyiv-Pardubice, $320 \mathrm{pp}$.

Tshikolovets V. V., Yakovlev R. V., Kosterin O. 2009b. The butterflies of Palaearetic Asia. Vol. 7. The Butterflies of Altai, Sayans and Tuva (South Siberia). Konvoj Ltd., Kyiv-Pardubice, 374 pp.

Tuzov V. K., Bogdanov P. V., Devyatkin A. L., Kaabak L. V., Korolev V. A., Murzin V. S., Samodurov G. D. \& TARASOV E. A. 1997. Guide to the butterflies of Russia and adjacent territories (Lepidoptera, Rhopalocera). Hesperiidae, Papilionidae, Pieridae, Satyridae. Volume 1. Pensoft, Sofia-Moscow, $480 \mathrm{pp}$.

WARECKI A. \& SIELEZNIEW M. 2008. Dryad Minois dryas (Lepidoptera, Nymphalidae) in south-eastern Poland: a recent range expansion or oversight of an endangered species? Polish Jurnal of Entomology 77: 191-198.

VAN SWAAY C. A. M., WARREN M. 1999. Red data book of European butterflies (Rhopalocera). Nature and Environment, No 99. Council of Europe Publishing, Strasbourg, 260 pp.

\section{STRESZCZENIE}

\section{[Zmiany rozmieszczenia Minois dryas (Scopoli, 1763) (Lepidoptera: Nymphalidae) w Polsce - przegląd badań i nowe dane]}

Minois dryas (Scopoli, 1763) w przeszlości zasiedlal wyspowo pólnocno-zachodnia, centralną i południową Polskę. Pod koniec lat 80-tych ub. wieku w związku z wymieraniem poszczególnych kolonii gatunek znany był tylko z jednego naturalnego stanowiska na południu kraju. Został uznany za krytycznie zagrożony wyginięciem i objęty ochroną prawną. W pierwszej dekadzie XXI wieku zostal ponownie odnaleziony w południowo-wschodniej części kraju, gdzie dotychczas znany był tylko z dwóch historycznych stanowisk w Olchowej koło Leska i Mokrej kolo Jarosławia. W pracy zebrano nowe i niepublikowane informacje na temat obserwacji tego gatunku, dokonanych na terenie Polski poludniowo-wschodniej w latach 2002-2011. M. dryas zostal po raz pierwszy stwierdzony na Pogórzu Przemyskim oraz na Pogórzu Dynowskim. Potwierdzono również jego występowanie w Kotlinie Sandomierskiej. 